\title{
Polymerase Chain Reaction Detection of Retinoblastoma Gene Deletions in Paraffin-Embedded Mouse Lung Adenocarcinomas ${ }^{1}$
}

\author{
Mark E. Churchill, ${ }^{2}$ M. Anne Gemmell, and Gayle E. Woloschak
}

Biological and Medical Research Division

Argonne National Laboratory

9700 S. Cass Avenue

Argonne, Illinois 60439-4833

Running Title: $\quad R b$ Gene Deletions in Radiation-induced Tumors

Key Words: . fission-spectrum neutrons; $\gamma$ rays; lung adenocarcinoma; radiationinduced tumors; retinoblastoma gene deletions

\section{DISCLAIMER}

\begin{abstract}
This report was prepared as an account of work sponsored by an agency of the United States Government. Neither the United States Government nor any agency thereof, nor any of their employees, makes any warranty, express or implied, or assumes any legal liability or responsibility for the accuracy, completeness, or usefulness of any information, apparatus, product, or process disclosed, or represents that its use would not infringe privately owned rights. Reference herein to any specific commercial product, process, or service by trade name, trademark, manufacturer, or otherwise does not necessarily constitute or imply its endorsement, recommendation, or favoring by the United States Government or any agency thereof. The views and opinions of authors expressed herein do not necessarily state or reflect those of the United States Government or any agency thereof.
\end{abstract}

DISTRIBUTION OF THIS DOCUMENT IS UNLIMITED<smiles></smiles>

'This work supported by the U.S. Department of Energy, Office of Health and Environmental Research, under Contract No. W-31-109-ENG-38.

${ }^{2}$ To whom correspondence should be addressed, at Biological and Medical Research Division, Argonne National Laboratory, 9700 South Cass Avenue,Argonne, IL 60439-4833. 


\section{DISCLAIMER}

Portions of this document may be illegible in electronic image products. Images are produced from the best available original document. 


\section{ABSTRACT}

A polymerase chain reaction (PCR) technique has been developed to detect deletions in the mouse retinoblastoma $(m R b)$ gene using microtomed sections from these paraffin-embedded radiation-induced and spontaneous tumors as the DNA source. Six $m R b$ gene exon fragments were amplified in a 40-cycle, 3-temperature PCR protocol. Absence of any of these fragments relative to control PCR products on a Southern blot indicated a deletion of that portion of the $m R b$ gene. Tumors chosen for analysis were lung adenocarcinomas that were judged to be the cause of death. Spontaneous tumors as well as those from irradiated mice $\left(569 \mathrm{cGy}\right.$ of ${ }^{60} \mathrm{Co} \gamma$ rays or $60 \mathrm{cGy}$ of JANUS neutrons which have been found to have approximately equal biological effectiveness) were analyzed for $m R b$ deletions. Tumors in six neutron-irradiated mice also had no $m R b$ deletions. However, one of six tumors from $\gamma$-irradiated mice (17\%) and 6 of 18 spontaneous tumors from unirradiated mice (33\%) showed a deletion in one or both $m R b$ alleles. All deletions detected were in the $5^{\prime}$ region of the $m R b$ gene. Information obtained from such studies of large numbers of preserved mouse tissues has the potential to aid in the identification of mechanisms of radiation-induced carcinogenesis. 


\section{INTRODUCTION}

Ionizing radiation is known to be both mutagenic and carcinogenic (1,2). Many studies have focused on in vitro radiation-induced transformation in cultured cells (3-5) and in vivo on malignant tumor formation in whole animals (6-9). It is widely accepted that radiation-induced cell killing and mutations are the result of DNA damage including DNA strand breaks, base modifications, insertions and deletions $(10,11)$. However, little is known about the specific molecular mechanisms by which ionizing radiation induces cellular transformation. We report the development of a $\mathrm{PCR}^{3}$ technique which allows detection of large DNA deletions in paraffin-embedded lung adenocarcinomas from mice irradiated with ${ }^{60} \mathrm{Co} \gamma$ rays or JANUS fission-spectrum neutrons.

From 1971-1986, Argonne National Laboratory conducted a series of large-scale studies of tumor incidence in approximately $40,000 \mathrm{BCF}_{1}$ mice irradiated with ${ }^{60} \mathrm{Co} \gamma$ rays or JANUS fission-spectrum neutrons $(8,9)$. Pathologic examinations of the mice were conducted to determine the effects of varying radiation doses and dose schedules on the formation of neoplasias classified as "lethal" or "contributing to death." The tumors and normal tissues were fixed in buffered formalin and preserved in paraffin blocks for later analyses. Although the quality of DNA in these paraffin-preserved tissues was generally not large enough for ordinary Southern blot studies, specific sequences from the DNA can

\footnotetext{
${ }^{3}$ Abbreviations Used: bp, base pair(s); LET, linear energy transfer; $\mathrm{Na}_{2} \mathrm{EDTA}$, ethylenediaminetetraacetic acid, disodium salt; PCR, polymerase chain reaction; SDS, sodium dodecyl sulfate; 20X SSC, 3.0 M $\mathrm{NaCl}, \quad 0.3 \quad M$ trisodium citrate, $\mathrm{pH}$ 7.4; Tris $\mathrm{HCl}$, tris[hydroxymethyl]aminomethane hydrochloride; Tween $20^{\circ}$, polyoxyethylenesorbitan monolaurate
} 
be amplified and detected using PCR technology (12-14). The preserved tissues from this $B C F_{1}$ mouse study thus have the potential to provide a wealth of information about the molecular genetics of radiation-induced tumor formation in mice.

The gene chosen for the initial study was the retinoblastoma $(R b)$ gene, which has been classified as a tumor suppressor gene or anti-oncogene because loss of both functional $R b$ alleles has been implicated in the development or progression of several types of neoplasms including retinoblastomas $(15,16)$, sarcomas $(17,18)$, small-cell lung carcinomas (19), non-small-cell lung malignancies (20), breast (21), ovarian (22), prostate (23), and bladder cancers (24). The "underphosphorylated" form of the $R b$ protein is thought to inhibit passage of cells from the G1 phase of the cell cycle into S phase $(25,26)$, thus inhibiting cell cycle progression. Since both low- and high-LET radiations can produce mutations by causing deletions in DNA (27), we reasoned that $R b$ deletions would likely be found in tumors which developed in irradiated mice.

PCR primers were designed based on the published mouse retinoblastoma $(m R b)$ cDNA sequence (28). Six $m R b$ fragments, ranging in size from $80-220 \mathrm{bp}$, were amplified using digested, paraffin-preserved mouse lung tissues as the DNA source. Southern blots of PCR products were used to determine the presence or absence of each fragment. Absence of one or more fragments on the Southern blot autoradiograph (relative to a standard gene) demonstrated a deletion of that portion of the $m R b$ gene in one or both $R b$ alleles. This technique enabled us to detect $m R b$ deletions in 6 of 18 (33\%) spontaneous lung adenocarcinomas and one of six (17\%) lung adenocarcinomas from $\gamma$-irradiated mice. No $m R b$ deletions were found in lung adenocarcinomas from six neutron-irradiated mice. These experiments demonstrate that this technique can be used to detect large deletions in the genomic DNA of specific genes from paraffin-preserved tissues. 
MATERIALS AND METHODS

cDNA clones. We thank the following individuls for generously providing cDNA clones: Dr. Dryja (Harvard Univ., Boston, MA) for $R b$ cDNA and Dr. David Baltimore (Rockefeller Univ., New York, NY) for Rag-1 cDNA.

Tissue Samples. During the Argonne mouse irradiation study, a database containing information on each mouse involved in the study was established. We selected paraffin blocks of mouse tissues for our study based on information from this database. Control mice and mice that had been irradiated with known doses of radiation were identified, and paraffin blocks containing normal lungs or lung adenocarcinomas from these mice were retrieved from the Argonne Tissue Repository for use in this study. $\mathrm{BCF}_{1}$ mice (C57BL/6 $\times \mathrm{BALB} / \mathrm{c}$ ) were bred in the Argonne animal facility. Mice entered the experiment at 16 weeks of age. Radiation facilities, dosimetry, and methods of exposure have been reported in detail by Grahn et al. (29) and Williamson and Frigerio (30). The tissues used in this study were derived from male mice irradiated with a single dose of either $569 \mathrm{cGy}$ of ${ }^{60} \mathrm{Co} \gamma$ rays or $60 \mathrm{cGy}$ of JANUS fission-spectrum neutrons (JANUS neutrons have a mean energy of $0.85 \mathrm{MeV}$ and a $\gamma$ ray contamination level of only $2.5 \%$ ). Control mice were not irradiated. The $\gamma$ ray and neutron doses chosen have approximately equal biological effectiveness in the $\mathrm{BCF}_{1}$ mouse $(8,9)$. Necropsies were performed by pathologists who determined the probable cause of death for each animal and preserved tissues by fixation in buffered formalin followed by embedding in paraffin blocks. Normal lung tissue from unirradiated mice (12 samples), $\gamma$-irradiated mice (six samples), and neutron-irradiated mice (six samples) were analyzed for $m R b$ deletions by PCR. Also, adenocarcinomas from unirradiated mice (18 samples), $\gamma$-irradiated mice (six 
samples), and neutron-irradiated mice (six samples) were similarly analyzed. All adenocarcinomas studied were determined by post-mortem analysis to be the cause of death of the animals.

DNA Sample Preparation. Paraffin tissues were prepared for PCR by the method of Wright and Manos (31). Blocks were microtomed ( 7 m sections), tissue was deparaffinized $2 \mathrm{X}$ with xylene, and xylene was removed by two washes in $100 \%$ ethanol, with the tissue collected by microfuging after each treatment. Microfuged tissue was dried briefly under vacuum and digested for $3 \mathrm{~h}$ at $50^{\circ} \mathrm{C}$ in $100 \mu \mathrm{L}$ of a buffer containing $50 \mathrm{mM}$ Tris $\mathrm{HCl}$; $\mathrm{pH} 8.5 ; 1 \mathrm{mM} \mathrm{Na} \mathrm{NDTA}_{2}$; $0.5 \%$ Tween and $200 \mu \mathrm{g} / \mathrm{mL}$ Proteinase $\mathrm{K}$. The enzyme was inactivated for $8 \mathrm{~min}$ at $95^{\circ} \mathrm{C}$, and $5 \mu \mathrm{L}$ of the digest was used without further purification as the DNA source in $50 \mu \mathrm{L}$ PCR reaction mixtures.

PCR Protocol. Primers (20-mers) for amplification of six segments of the $m R b$ gene were designed according to the cDNA sequence (from $5^{\prime}$ to $3^{\prime}$ ) published in Bernards et al. (28):

\begin{tabular}{|c|c|c|c|}
\hline Segment \# & Sense Primer & Antisense Primer & $\begin{array}{c}\text { Length of Segment } \\
\text { Amplified }\end{array}$ \\
\hline 1 & $601-620$ & $701-720$ & $120 \mathrm{bp}$ \\
\hline 2 & $901-920$ & $1101-1120$ & $220 \mathrm{bp}$ \\
\hline 3 & $1501-1520$ & $1561-1580$ & $80 \mathrm{bp}$ \\
\hline 4 & $2001-2020$ & $2146-2165$ & $165 \mathrm{bp}$ \\
\hline 5 & $2481-2500$ & $2572-2591$ & $111 \mathrm{bp}$ \\
\hline 6 & $3501-3520$ & $3575-3594$ & $94 \mathrm{bp}$ \\
\hline
\end{tabular}


Segments 1-5 are contained in the coding region, and segment 6 is contained in the $3^{\prime}$ untranslated region. Sequences of the primers were:

$\begin{array}{ll} & 5^{\prime} \\ \text { Sense } 1 & 3^{\prime} \\ \text { Anti } 1 & \text { TTACACAACCCAGCAGTGCG } \\ \text { Sense } 2 & \text { TCGAGGTTCTCTGTAAAGAA } \\ \text { Anti } 2 & \text { GGATCAGTCTGAAGTGTTTT } \\ \text { Sense } 3 & \text { GCAAACTCCTAAATGACAAC } \\ \text { Anti } 3 & \text { TCTGCTATACGTAGCCATTA } \\ \text { Sense } 4 & \text { TTGAAATCTACCTCCCTTGC } \\ \text { Anti } 4 & \text { TCTCATGAGCTCATACTCAT } \\ \text { Sense } 5 & \text { GGTAACATCTATATATCACC } \\ \text { Anti } 5 & \text { TGATTCACCAATTGAGACCA } \\ \text { Sense } 6 & \text { ACAGATTTCATACCTCAGAC } \\ \text { Anti } 6 & \text { CAACCTTGGAGTATTATCAA }\end{array}$

Primers (20-mers) for amplification of the Rag-1 gene standard were based on the cDNA sequence published by Schatz et al. (32). The sense primer (1063-1082) wäs 5'CTATTGTCCCTCTTGCCGAT-3' and the antisense primer (1571-1590) was 5'GGTTGAAAAATCTGCCTCCC-3', giving a 528-bp fragment.

PCR reaction mixtures $(50 \mu \mathrm{L})$ were run in a Perkin-Elmer Cetus DNA Thermal Cycler and contained: $10 \mathrm{mM}$ Tris $\mathrm{HCl}, \mathrm{pH} 8.3 ; 50 \mathrm{mM} \mathrm{KCl} ; 1.5 \mathrm{mM} \mathrm{MgCl} ; 200 \mu \mathrm{M}$ each dATP, dCTP, dGTP, dTTP; $0.3 \mu \mathrm{M}$ each primer; $5.0 \mu \mathrm{L}$ tissue digest; and a $45 \mu \mathrm{L}$ mineral oil overlay. This reaction mixture was held at $94^{\circ} \mathrm{C}$ for $5 \mathrm{~min} ; 1.25$ units of Taq polymerase was added (hot start), and the following protocol was used for amplification: 
$1 \min 94^{\circ} \mathrm{C} / 1 \min 42^{\circ} \mathrm{C} / 2 \min 65^{\circ} \mathrm{C}$

$7 \min 65^{\circ} \mathrm{C}$
40 cycles

1 cycle

Amplified reaction mixtures were stored at $-20^{\circ} \mathrm{C}$ until used for electrophoresis.

Amplifications of the $m R b$ and $R a g-1$ genes were done under the same conditions.

Southern Blot Procedure. PCR reaction mixtures $(18 \mu \mathrm{L})$ of the $m R b$ gene were run on a 3.2\% NuSieve 3:1 Agarose (FMC BioProducts, Rockland, ME) gel at $90 \mathrm{~mA}$ for 4 h. The gel was denatured $2 \mathrm{X}$ for $30 \mathrm{~min}$ in $0.6 \mathrm{M} \mathrm{NaOH} / 1.5 . \mathrm{M} \mathrm{NaCl}$ and neutralized $2 \mathrm{X}$ for $30 \mathrm{~min}$ in $1.5 \mathrm{M}$ Tris $\mathrm{HCl} / 1.5 \mathrm{M} \mathrm{NaCl}, \mathrm{pH}$ 8.0. The DNA was transferred to a neutral nylon membrane (MSI, West Borough, MA) with 10X SSC transfer buffer. The membrane was rinsed, dried, and UV-crosslinked. Membranes were hybridized to ${ }^{32} \mathrm{P}$ random hexanucleotide-labeled $m R b$-containing plasmid in Speed-Hyb solution (BIOS Corp., New Haven, CT) at $53^{\circ} \mathrm{C}$. Membranes were washed $4 \mathrm{X}$ in $2 \mathrm{X} \mathrm{SSC}, 0.5 \%$ SDS at $53^{\circ} \mathrm{C}$, dried, and autoradiographed.

PCR reaction mixtures of the Rag-1 gene were run similarly except for the following: $1.5 \% \mathrm{ME}$ agarose gel was run at $80 \mathrm{~V}$ for $4 \mathrm{~h}$; the gel was denatured and neutralized only $1 \mathrm{X}$ each; the Rag-1 plasmid was used for probing; and washing was in $0.5 \mathrm{X}$ SSC, $0.5 \%$ SDS $3 \mathrm{X}$ at $53^{\circ} \mathrm{C}$.

Autoradiographs were scanned on a Hirschmann Elscript 400 microdensitometer for quantitation of band intensities.

Method of Quantitating $m R b$ Deletions. The basic approach for detecting deletions was to amplify the six $m R b$ PCR segments from control and tumor tissues and to quantitate the intensity of autoradiograph bands by microdensitometry. Ideally, if one or more PCR segments were present in control tissues but absent in a tumor sample, the tumor sample had that portion of the $m R b$ gene deleted. 
Because it was impossible to eliminate all normal tissue from the tumor samples, bands from a tumor tissue with a deletion are lighter than bands from control tissues, but may not be completely absent. Furthermore, the intensity of bands will be different on different blots due to differences in amount of probe used, efficiency of crosslinking, etc. Thus, PCR fragment \#4 (shown in Figures 1 and 2) was amplified using $m R b$ cDNA plasmid. When a Southern blot containing PCR amplifications of tumor or normal paraffin tissues was run, a known amount of the standard band \#4 was included on the gel. The intensity of each band on the gel was compared with the intensity of the standard band, giving a mathematical ratio that allows standardization of band intensities from gel to gel and sample to sample. We designate this ratio $R 1$ :

$$
R 1=\frac{\text { intensity of paraffin } m R b \text { band }}{\text { intensity of standard } m R b \text { band }}
$$

Another source of sample variation could be caused by the efficiency of amplification and the amount of tissue used from sample to sample; to correct this variation a standard gene that was not deleted in tumors (Rag-1) was amplified, and the intensity of this band was used to correct for amplification efficiency and amount of tissue used. A 528-bp segment of Rag-1 gene was chosen as an undeleted standard, for which we have never found any deletions in adenocarcinomas. The intensity of the band produced was compared to the intensity of a standard Rag-1 band prepared by PCR of a Rag- 1 cDNA plasmid. The ratio $R 2$ is designated: 


$$
R 2=\frac{\text { intensity of paraffin } R a g-1 \text { band }}{\text { intensity of standard } R a g-1 \text { band }}
$$

In order to evaluate whether one $m R b$ band was less abundant than another, each band was assigned a ratio $R$ :

$$
R=\frac{R I}{R 2}
$$

We have determined that bands from control tissues had $R$ values that were greater than 0.2 , often as large as 5.0, while bands from tumor tissues with $m R b$ deletions had $\mathrm{R}$ values that were small (usually 0 to 0.1 ). A large differential in $R$ values was observed between normal and deleted bands. Very few questionable PCR products were evident so that deletions were generally very obvious, often visually, but especially from the $R$ values. 


\section{RESULTS}

None of the 18 normal lung tissues examined showed deletion of the six $m R b$ fragments tested. This was true of normal lungs from both unirradiated and irradiated animals. The $R$ values for all bands amplified from normal lung tissues were 0.2 or greater, indicating the presence of the band. For tumor tissues, only bands with $R$ values less than 0.2 (usually less than 0.1 ) were considered to be deleted. One paraffin block containing normal lung tissue consistently failed to amplify either $m R b$ or $R a g-1$ fragments because of extensive necrosis of the tissue before preservation. This tissue, which was treated the same as all others, served as a negative PCR control.

Figure 1 shows a typical autoradiograph of the six $m R b$ fragments amplified from a normal lung tissue sample (Lanes 1-6). Lane 7 is the $m R b$ standard band containing a known quantity of fragment \#4. Lane 8 is the Rag-1 fragment amplified from the same tissue sample. Lane 9 is the Rag-1 standard band containing a known amount of the Rag-1 fragment. All six $m R b$ bands are clearly present, and each has a calculated $\mathrm{R}$ value greater than 0.2 . The $R$ values were $0.37,0.37,1.17,1.27,1.63$, and 2.12 for bands $1-6$, respectively.

Figure 2 shows a typical autoradiograph of the six $m R b$ fragments amplified from an adenocarcinoma in which $m R b$ fragments 1,2 , and 3 are deleted. Lanes $1-3$ are fragments from the deleted portion of the $m R b$ gene, while lanes 4-6 are fragments from the part of the $m R b$ gene that is still present. Lanes 7, 8, and 9 are as for Figure 1 . The $R$ values for the $m R b$ bands were $0,0,0.14,0.36,0.70$, and 1.20 for lanes $1-6$, respectively. Bands 1 and 2 are not visible. Band 3 is detectable, but the $R$ value of 0.14 indicates that the band is deleted from the tumor sample. Thus, for this tumor, the 
portion of the $m R b$ gene corresponding to fragments 1,2 , and 3 are deleted in at least one allele.

Normal lung tissue from unirradiated mice (12 samples), $\gamma$-irradiated mice (six samples), and neutron-irradiated mice (six samples) showed the presence of all $m R b$ bands in all blots $(R>0.2)$. All adenocarcinomas studied were determined by postmortem analysis to be the cause of death of the animals. In 12 of 18 adenocarcinomas that developed in unirradiated mice, no $m R b$ deletions were detected. In 6 of 18 (33\%) spontaneous adenocarcinomas, $m R b$ deletions were detected. Four of the tumors had a deletion of fragments 1 and 2, while two of the tumors had a deletion of fragments 1,2 , and 3. In 5. of 6 adenocarcinomas from $\gamma$-irradiated animals, no $m R b$ deletions were detected. One of the tumors had a deletion of fragments 2 and 3 . In six adenocarcinomas that developed in neutron-irradiated mice, none showed an $m R b$ deletion. These data are summarized in Table 1. 


\section{DISCUSSION}

The paraffin-preserved mouse tissues used in this study provide a unique opportunity to study tumors in irradiated animals. Scrupulously kept records are available for each animal in the study, and statistics have been calculated for lifeshortening and for the formation of each tumor type. Studies of the molecular biology of radiation-induced tumors would be greatly enhanced by the ability to analyze individual genes from the tumors. Because of the fact that we and others (12) have found that the DNA in paraffin-preserved tissues is highly degraded, PCR technology provides the only feasible method at present for detecting mutations in such tissues.

One.goal of this study was to determine whether the preserved tissues were of a sufficient quality to analyze mutations by PCR. Large deletions are the easiest mutations to detect in such tissues since the presence or absence of specific PCR products is easily achieved. It is known that both low- and high-LET radiations can cause mutations by inducing deletions (27), and that deletions in the $R b$ gene are found in tumors derived from many different organs. Thus, the $R b$ gene was chosen as the initial gene for study in the paraffin-preserved tissues. Lung adenocarcinomas were chosen as the tumor of interest for at least three reasons: (1) a large number of samples were available because this tumor type is one of the most frequently found in $\mathrm{BCF}_{1}$ mice $(8,9)$, (2) separation of normal from tumor tissue in paraffin blocks was facilitated by the distinctive appearance and generally large size of the tumors, and (3) the $R b$ gene is known to be deleted frequently in human lung adenocarcinomas (20).

Initial experiments determined that only $m R b$ fragments smaller than $250 \mathrm{bp}$ amplified reproducibly from the paraffin tissue samples. This was not true for the Rag-1 standard gene, for which the 528-bp segment amplified reproducibly for each tissue. The 
reason may be related to the low GC content of the $m R b$ coding region and, therefore, of the PCR primers. PCR generally works best with primers having a GC content of 50-60\% (31). All but one of the $m R b$ primers used in this study have low melting temperatures and a GC content of 35-45\%. By testing a large number of primer pairs, six $m R b$ fragments were found that amplified reproducibly.

It was not practical to amplify the entire $m R b$ gene for two reasons: (1) a large number of fragments sized $250 \mathrm{bp}$ or smaller would be necessary to amplify a $4.7-\mathrm{kb}$ gene, and (2) the intron structure for the entire $m R b$ gene is not known. The technique of detecting $R b$ deletions used here has several inherent limitations. First, if the fragment being amplified is present in one allele but deleted in the other, a band will still appear on the Southern blot. Since both alleles of the $R b$ gene are usually mutated in tumors $(33,34)$, this limitation is reasonable. Second, deletions in the $m R b$ gene that fall between PCR fragments in the gene sequence will not be detected. Because this study focused exclusively on $m R b$ coding regions, deletions in introns or in non-amplified coding regions of the $m R b$ gene would be missed using this approach. However, large deletions, sometimes of the entire gene, are often found in retinoblastomas (33), so it is reasonable to expect that tumors will be found having large $m R b$ deletions that can be detected by our technique. Third, point mutations or small deletions and insertions will not be detected. A point mutation in the primer sequence might prevent primer binding during the PCR annealing step. However, our annealing temperature of $42^{\circ} \mathrm{C}$ (necessary because of the low GC content of the $m R b$ primers) is not sufficiently stringent to detect point mutations in the primer sequence. Future experiments aimed at increasing the resolution of the technique are being planned. 
All the $m R b$ deletions found in $\mathrm{BCF}_{1}$ lung adenocarcinomas were located at the $5^{\prime}$ end of the gene, involving fragments 1,2 , and 3 , thus generating alterations in the $\mathrm{N}$ terminus of the $R b$ protein. This result is in contrast to results obtained in human retinoblastomas, in which deletions have been found throughout the entire gene $(33,35)$. The functional significance of $5^{\prime}$ deletions in the mouse adenocarcinomas is not known. The $R b$ protein is a DNA-binding protein (34), and association of $R b$ protein with viral transforming proteins such as SV40 large-T antigen or adenovirus E1A protein, inactivates it (36). The $m R b$ deletions observed in the tumors examined in this report could cause a total absence of $m R b$ protein in cells or to a deletion of a portion of the protein required for a critical cellular function. A region of the amino acid sequence in human $R b$ from residues 379 to 792 has been identified as being required for binding of $R b$ protein to SV40 large-T antigen and E1A protein (36). However, the deletion of $m R b$ gene fragments 1 and 2 in mice is not in this region (they would cover amino acid residues 169 to 347 ). The presence of so many deletions at the $\mathrm{N}$-terminal end of the $R b$ protein is highly suggestive that the presence of this region is essential for the normal function of $R b$ protein in mice.

Contrary to our expectation in designing this study, all but one $m R b$ deletion was found in spontaneous tumors rather than in tumors from irradiated mice. It is obvious that deletions in the $m R b$ gene occur commonly in the absence of irradiation. Our data suggest that $\gamma$ - or neutron-irradiation does not cause an increased frequency of $m R b$ deletions. The observed increase in frequency of lung adenocarcinomas upon $\gamma$ - or neutron-irradiation of mice $(8,9)$ is apparently the result of a mechanism other than $m R b$ deletion. Experiments are underway to examine these tissues for lesions in other dominant and suppressor oncogenes. 
ACKNOWLEDGEMENTS

The authors wish to thank Dr. Bruce Carnes and Ms. Betty Jean Wright for their expert assistance in selecting tumors for study, Ms. Kay Bexson for excellent secretarial assistance, and Drs. Carol Giometti, Radoje Drmanc, Lydia Ling-Indeck, and Frank Collart for reviewing this manuscript. 


\section{REFERENCES}

1. Upton, A. C. Biological aspects of radiation carcinogenesis. In: J. D. Boice and J. F. Fraumeni (eds.), Radiation Carcinogenesis: Epidemiology and Biological Significance, p. 9. New York: Raven Press, 1984.

2. Shigematsu, I., and Kagan, A. Cancer in atomic bomb survivors. GANN Monograph on Cancer Research, 32, Tokyo: Japan Scientific Societies Press and New York: Plenum Press, 1986.

3. Borek, C. Malignant transformation in vitro: Criteria, biological markers, and application to environmental screening of carcinogens. Radiat. Res., 70: 209-232, 1979.

4. Elkind, M. M., and Han, A. Neoplastic transformation and dose fractionation: Does repair of damage play a role? Radiat. Res., 79: 233-240, 1979.

5. Kennedy, A. R., Cairns, J., and Little, J. B. Timing of the steps in transformation of C3H 10T1/2 cells by X-irradiation. Nature, 307: 85-86, 1984.

6. United Nations Scientific Committee on the Effects of Atomic Radiation. Sources and effects of ionizing radiation. Report to the General Assembly, with annexes. New York: United Nations, 1977. 
7. United Nations Scientific Committee on the Effects of Atomic Radiation. Ionizing radiation: Sources and biological effects. Report to the General Assembly, with annexes. New York: United Nations, 1982.

8. Grahn, D., Thomson, J. F., and Carnes, B. Relative biological effectiveness (RBE) of fission neutrons and gamma rays at occupational exposure levels, Volume III: Studies on the gross microscopic pathology observed at death of mice exposed to 60 equal once-seekly doses of fission neutrons and gamma rays. U. S. Nuclear Regulatory Commission publication NUREG/CR-4704 ANL-86-33, Vol. 3, 1990.

9. Grahn, D., Lombard, L. S., and Carnes, B. A. The comparative tumorigenic effects of fission neutrons and cobalt-60 $\gamma$ rays in the $\mathrm{B} \mathrm{CF}_{1}$ mouse. Radiat. Res. 129: 1936, 1992.

10. Yunis, J. J. The chromosomal basis of human neoplasia. Science, 221: 227-236, 1983.

11. Hutchinson, F. Chemical changes induced in DNA by ionizing radiation. Progr. Nucleic Acid Res. Mol. Biol., 32: 115-125, 1985.

12. Goeltz, S. E., Hamilton, S. R., and Vogelstein, B. Purification of DNA from formaldehyde-fixed and paraffin-embedded human tissue. Biochem. Biophys. Res. Comm., 130: 118-126, 1985. 
13. Impraim, C. C., Saiki, R. K., Erlich, H. A., and Teplitz, R. L. Analysis of DNA extracted from formalin-fixed, paraffin-embedded tissues by enzymatic amplification and hybridization with sequence-specific oligonucleotides. Biochem. Biophys. Res. Comm., 142: 710-716, 1987.

14. Shibata, D. K., Arnheim, N., and Martin, W. J. Detection of human papilloma virus in paraffin-embedded tissue using the polymerase chain reaction. J. Exp. Med., 167: 225-230, 1988.

15. Friend, S. H., Horowitz, J. M., Gerber, M. R., Wang, X.-F., Bogenmann, E., Li, F. P., and Weinberg, R. A. Deletions of a DNA sequence in retinoblastomas and mesenchymal tumors: Organization of the sequence and its encoded protein. Proc. Natl. Acad. Sci. USA, 84: 9059-9063, 1987.

16. Fung, Y.-K. T., Murphree, A. L., TैAng, A., Qian, J., Hinrichs, S. H., and Benedict, W. F. Structural evidence for the authenticity of the human retinoblastoma gene. Science, 236: 1657-1661, 1987.

17. Dunn, J. M., Phillips, R. A., Becker, A. J., and Gallie, B. L. Identification of germline and somatic mutations affecting the retinoblastoma gene. Science, 241: 1797-1800, 1988. 
18. Horowitz, J. M., Yandell, D. W., Park, S-H., Canning, S., Whyte, P., Buchkovich, K. Harlow, E., Weinberg, R. A., and Dryja, T. P. Point mutational inactivation of the retinoblastoma antioncogene. Science, 243: 937-940, 1989.

19. Harbour, J. W., Lai, S-L., Whang-Peng, J., Gazdar, A. F., Minna, J. D., Kaye, F. J. Abnormalities in structure and expression of the human retinoblastoma gene in SCLC. Science, 241: 353-357, 1988.

20. Weston, A., Willey, J. C., Modali, R., Sugimura, H., McDowell, E. M., Resau, J., Light, B., Haugen, A., Mann, D. L., Trump, B. F., and Harris, C. C. Differential DNA sequence deletions from chromosomes $3,11,13$, and 17 in squamous cell carcinoma, large cell carcinoma, and adenocarcinoma of the human lung. Proc. Natl. Acad. Sci. USA, 86: 5099-5103, 1989.

21. Lee, E. Y.-H. P., To, H., Shew, J.-Y., Bookstein, R., Scully, P., and Lee, W.-H. Inactivation of the retinoblastoma susceptibility gene in human breast cancers. Science, 241: 218-221, 1988.

22. Li, S. B., Schwartz, P. E., Lee, W. H., Yang-Feng, T. L. Allele loss at the retinoblastoma locus in human ovarian cancer. J. Natl. Cancer Inst., 83: 637-640, 1991. 
23. Bookstein, R., Shew, J.-Y., Chen, P.-L., Scully, P., and Lee, W.-H. Suppression of tumorigenicity of human prostate carcinoma cells by replacing a mutated $R b$ gene. Science, 247: 712-715, 1990.

24. Horowitz, J. M., Park, S.-H., Bogenmann, E., Cheng, J.-C., Yandell, D. W., Kay, F. J., Minna, J. D., Dryja, T. P., and Weinberg, R. A. Frequent inactivation of the retinoblastoma anti-oncogene is restricted to a subset of human tumor cells. Proc. Natl. Acad. Sci. USA, 87:2775-2779, 1990.

25. Buchkovich, K., Duffy, L., and Harlow, E. The retinoblastoma protein is phosphorylated during specific phases of the cell cycle. Cell, 58: 1097-1105, 1989.

26. Chen, P.-L., Scully, P., Shew, J.-Y., Wang, J. Y. J., and Lee, W.-H. Phosphorylation of the retinoblastoma gene product is modulated during the cell cycle and cellular differentiation. Cell, 58: 1193-1198, 1989.

27. Breimer, L. H. Ionizing radiation-induced mutagenesis. Br. J. Cancer, 57: 6-18, 1988.

28. Bernards, R., Schackleford, G. M., Gerber, M. R., Horowitz, J. M., Friend, S. H., Schartl, M., Bogenmann, E., Rapaport, J. M., McGee, T., Dryja, T. P., and Weinberg, R. A. Structure and expression of the murine retinoblastoma gene and characterization of its encoded protein. Proc. Natl. Acad. Sci. USA, 86: 6474-6478, 1989. 
29. Grahn, D., Ainsworth, E. J., Williamson, F. S., and Fry, R. J. M. A program to study fission neutron-induced chronic injury in cells, tissues and animal populations, utilizing the JANUS reactor of the Argonne National Laboratory. Radiobiological Applications of Neutron Irradiation, International Atomic Energy Agency, Vienna: 211-228, 1972.

30. Williamson, F. S., and Frigerio, N. A. Field mapping and depth dosimetry in the JANUS high flux irradiation room - a fast neutron facility for biological research. In: G. Burger, M. Schraube, and H. G. Ebert (eds.), Proceedings of the First Symposium on Neutron Dosimetry in Biology and Medicine, pp. 743-755. Luxembourg: Commission of the European Communities, 1972.

31. Wright, D. K., and Manos, M. M. Sample preparation from paraffin-embedded tissues. In: M. A. Innis, D. H. Gelfand, J. J. Sninsky, and T. J. White (eds.), PCR Protocols: a Guide to Methods and Applications, 153-158, San Diego: Academic Press, 1990.

32. Schatz, D. G., Oettinger, M. A., and Baltimore, D. The V(D)J recombination activating gene, Rag-1. Cell, 59: 1035-1048, 1989.

33. Dunn, J. M., Zhu, X., Gallie, B. L., and Phillips, R. A. Characterization of mutations in the $R b 1$ gene. In: W. Cavanee, N. Hastie, and E. Stanbridge (eds.), Current Communications in Molecular Biology, Recessive oncogenes and tumor suppression, 93-100. New York: Cold Spring Harbor Laboratory Press, 1989. 
34. Stanbridge, E. J. Human tumor suppressor genes. Annu. Rev. Genet., 24: 615$657,1990$.

35. Kloss, K., Wahrisch, P., Greger, V., Messmer, E., Fritze, H., Hopping, W., Passarge, E., and Horsthemke, B. Characterization of deletions at the retinoblastoma locus in patients with bilateral retinoblastoma. Amer. J. Med. Genet., 39: 196-200, 1991.

36. Kaelin, W. G., Ewen, M. E., and Livingston, D. M. Definition of the minimal Simian Virus 40 large $T$ antigen- and adenovirus E1A-binding domain in the retinoblastoma gene product. Mol. Cell. Biol., 10: 3761-3769, 1990. 
Table 1. $m R b$ deletions detected in $\mathrm{BCF}_{1}$ mouse lung adenocarcinomas. PCR analyses were used to detect deletions in DNA derived from lung adenocarcinomas that arose spontaneously or following $\gamma$-ray or JANUS neutron exposure. Results express the percentage of tumors demonstrating at least one $m R b$ gene deletion.

\begin{tabular}{ccc}
\hline Irradiation condition & $\begin{array}{c}\text { Number of } \\
\text { adenocarcinomas tested }\end{array}$ & Number of $m R b$ \\
deletions found (\%)
\end{tabular}

${ }^{a}$ Deletions were not found in 12 normal lung tissues from irradiated and 6 normal lung tissues from untreated mice.

${ }^{b}$ Animals received a single $569 \mathrm{cGy}$ dose of ${ }^{60} \mathrm{Co} \gamma$ rays in $20 \mathrm{~min}$.

${ }^{c}$ Animals received a single $60 \mathrm{cGy}$ dose of JANUS fission-spectrum neutrons in $20 \mathrm{~min}$. 


\section{FIGURE LEGENDS}

Figure 1. Autoradiographs of the Southern blots obtained from PCR amplification of a normal lung tissue sample and hybridization to $m R b \mathrm{cDNA}$. Lanes 1-6: $m R b$ fragments of lengths $120,220,80,165,111$, and $94 \mathrm{bp}$, respectively. Lane 7: Standard $m R b$ 165-bp PCR product (fragment \#4). Lane 8: Rag-1 528-bp fragment amplified from the same lung tissue. Lane 9: Standard Rag-1 528-bp PCR product. All $m R b$ bands have an $R$ value greater than 0.2 (as described in text).

Figure 2. Autoradiographs of the Southern blots obtained from PCR amplification of a lung adenocarcinoma sample and hybridization to $m R b$ cDNA. Lanes 1-6: $m R b$ fragments as in Figure 1. Lane 7: Standard $m R b$ 165-bp PCR product (fragment \#4). Lane 8: Rag-1 528-bp PCR product amplified from the same adenocarcinoma tissue. Lane 9: Standard Rag1 528-bp PCR product. $m R b$ bands 1 and 2 are not detectable, and band 3 has $R=0.14$. Thus, these three bands are deleted in the adenocarcinoma. $m R b$ bands 4-6 are not deleted $(\mathrm{R}>$ $0.2)$. 
$\cdot b_{1}$
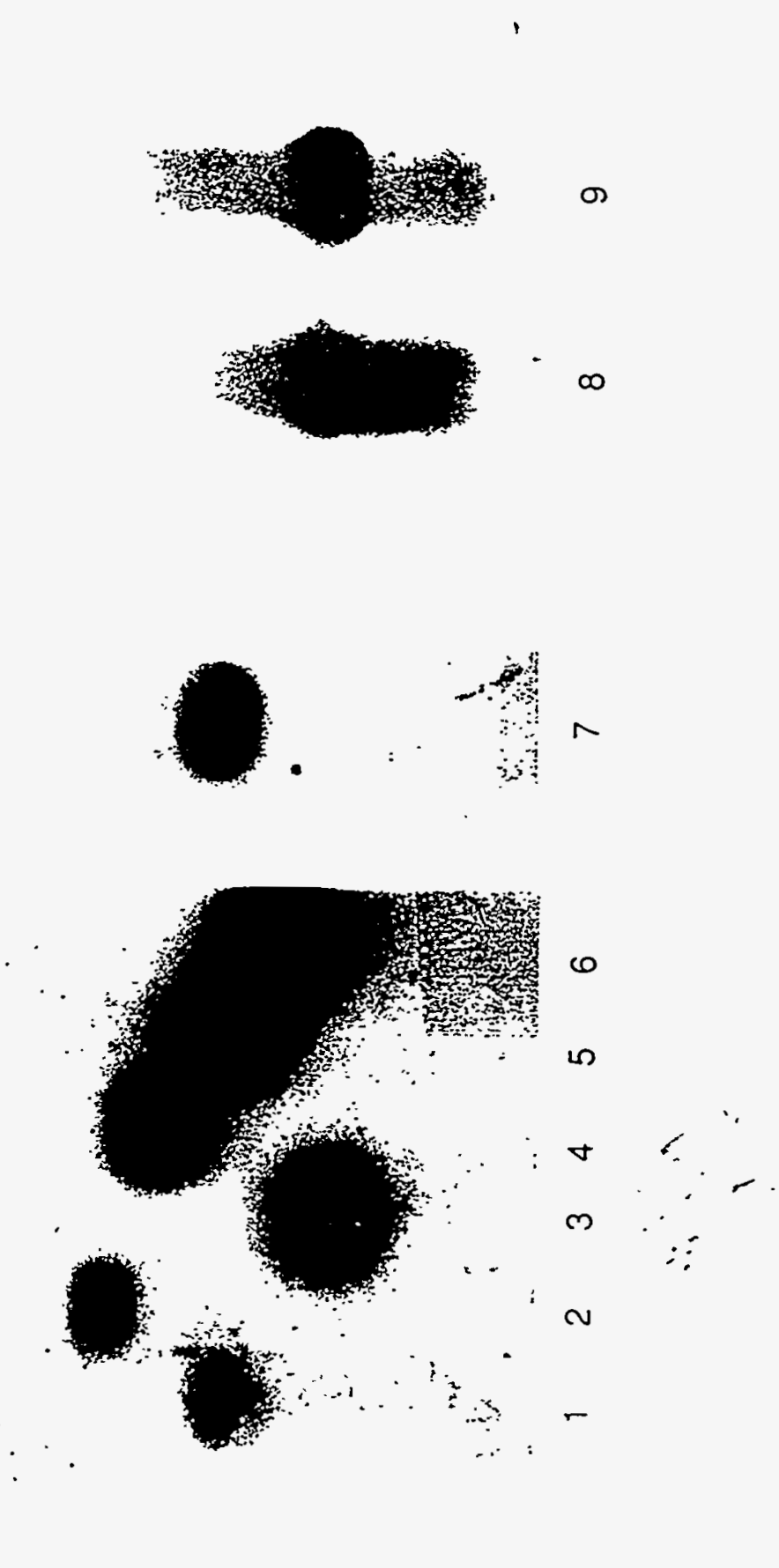
$+6, y$
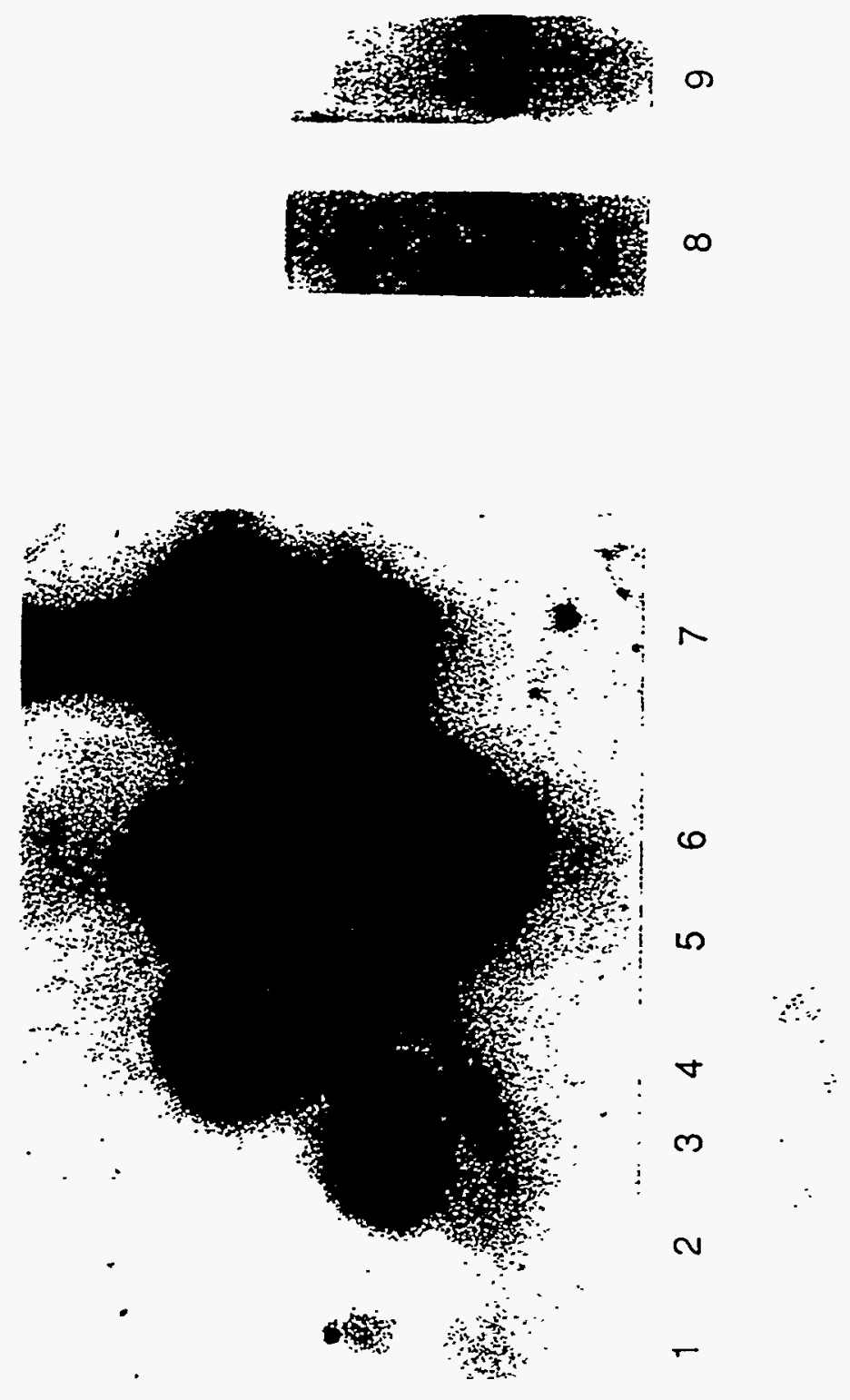